\title{
Relationship between zooplankton richness and area in Brazilian lakes: comparing natural and artificial lakes and trends
}

\author{
Relaçóes entre a riqueza do zooplâncton e a área em lagos brasileiros: comparando lagos \\ naturais e artificiais e tendências
}

Luisa Orbitelli Longato ${ }^{1}$, Iuri Emmanuel de Paula Ferreira ${ }^{1}$ and Gilmar Perbiche-Neves ${ }^{1 *}$

${ }^{1}$ Centro de Ciências da Natureza - CCN, Universidade Federal de São Carlos - UFSCar, Rodovia Lauri Simôes de Barros, SP 189, s/n, Km 12, CEP 18245-970, Buri, SP, Brasil

*e-mail: gilmarperbiche83@gmail.com

Cite as: Longato, L.O., Ferreira, I.E.P. and Perbiche-Neves, G. Relationship between zooplankton richness and area in Brazilian lakes: comparing natural and artificial lakes and trends. Acta Limnologica Brasiliensia, 2018, vol. 30, e309.

\begin{abstract}
Aim: We analyzed the relationship between zooplankton species richness and the area of 34 natural and 55 artificial lakes in Brazil (total of 89), with area varying between 0.01 to $2,430 \mathrm{~km}^{2}$. Methods: A total of 33 studies were found in the specialized bibliography, containing data from zooplankton sampled in the limnetic areas, here analyzed through descriptive statistics, nonparametric group comparisons, Spearman correlation, and non-linear regression. Results: The relationship between zooplankton richness and area in Brazilian lakes depend both on the size and type of the environments. Contradicting aspects of the biogeographic theory, in small environments (up to $6 \mathrm{~km}^{2}$ ) there is no significant influence of the area on the richness, whether it is natural (ponds) or artificial (dams, reservoirs). The natural lakes present greater richness and habitat variation independent of the size, possibly due to a more diverse composition of niches. Large natural lakes are scarce in Brazil but, with dams, area and zooplankton richness are positively correlated on an intermediate scale, up to $39 \mathrm{~km}^{2}$, critical point of size from which species' richness stabilizes. Conclusions: For the artificial lakes of large or intermediate size in Brazil, area and richness of microcrustaceans have a point from which richness starts to stabilize, as would be expected by the biogeographic theory. But in small size environments there is no evidence confirming this association. Also, it is observed that the natural lakes present higher and more variable values for richness than the artificial ones.
\end{abstract}

Keywords: Cladocera; Copepoda; ecology; diversity.

Resumo: Objetivo: Nós analisamos as relaçóes entre a riqueza de espécies zooplanctônicas e a área de 34 lagos naturais e 55 artificiais no Brasil (total de 89), lagos com tamanhos variando entre 0,01 e $2430 \mathrm{~km}^{2}$. Métodos: Foram consultados 33 artigos disponíveis na bibliografia especializada, contendo dados de zooplâncton amostrados nas zonas limnéticas, analisados nesse estudo por meio de estatísticas descritivas, correlação de Spearman e regressão não-linear. Resultados: A relação entre a riqueza de espécie zooplanctônicas e a área de lagos brasileiros depende do tamanho e do tipo de ambiente. Contradizendo aspectos biogeográficos teóricos, em ambientes pequenos (até $6 \mathrm{~km}^{2}$ ) não há influência significativa da área sobre a riqueza, em lagos naturais e artificiais (reservatórios e açudes). Lagos naturais apresentam maiores riquezas e variação de habitat independente do tamanho, possivelmente devido a composiçấo mais diversa de nichos. Grandes lagos naturais são escassos no Brasil, mas em reservatórios, a area e a riqueza do zooplâncton são positivamente correlacionadas em uma escala intermediária, até $39 \mathrm{~km}^{2}$, um ponto crítico de tamanho de área para que a riqueza estabilize. Conclusóes: Para lagoas artificias de tamanho grande ou intermediário no Brasil há um 
ponto no qual a riqueza estabiliza, como esperando nas teorias biogeográficas. Porém em ambientes pequenos não há evidências dessa relação. Também foi observados que lagos naturais exibem valores de riqueza maiores e mais variados do que os artificiais.

Palavras-chave: Cladocera; Copepoda; ecologia; diversidade.

\section{Introduction}

Biodiversity is a widely used term but its definition is not always clear. In a simple and robust way, biodiversity is commonly measured by the species' richness (a kind of diversity alpha, local), referring to the number of species that inhabit a specific area or sample unit (Barros, 2007).

The increase of species richness (S) with area (A) is one of the fundamental rules in ecology and biogeography. Many studies report, characterize, and interpret the mechanisms of relations of species-area (SARs), practically for all biomes and taxa (Connor \& McCoy, 1979, 2001; Williamson, 1988; Rosenzweig, 1995; Lomolino, 2001; Drakare et al., 2006; Albert \& Reis, 2011; Perbiche-Neves et al., 2014). Many studies confirm that this tendency of richness increases with area.

There are different ways to establish the best methods to analyze these relations. Some revisions have been published to try to standardize them (Dengler, 2009), however because of the number of biotic and abiotic factors acting on the communities, points of stabilization of richness increases lacks in literature, presenting a gap in knowledge about this variation. For example, the estimation of this critical point could be helpful for the sizing of environmental conservation units pointing if a minimum size of area is necessary to be considered for stabilizing the species richness of a selected community.

An increasing species-area relation was observed for fish (Albert $\&$ Reis, 2011) and for zooplankton, varying with the area of eco-regions (Abell et al., 2008; Perbiche-Neves et al., 2014), referring to the hydrographic basins. The highest neo-tropical number of species of fish and zooplankton occurs in the Amazon and Paraná River basins (Albert $\&$ Reis, 2011; Perbiche-Neves et al., 2014).

In Brazil, there are no studies that compared zooplankton diversity between natural and artificial lakes. Most of the studies focus on artificial lakes, especially reservoirs for hydropower generation (Silva \& Perbiche-Neves, 2016). Brazilian natural lakes are formed by erosion or deposition in river banks, for example in Amazon, Doce, Paraguay, and Paraná River basins. Generally, natural lakes are older than artificial lakes, which were constructed after the 1950's for hydropower generation, aquiculture, or water supply.

Both natural and artificial lakes tend to have eutrophication of their waters, slowly or quickly, depending on several variables, such as nutrients concentrations, depth, water retention time, etc. Due to the age and historical processes, natural lakes have more species than artificial lakes, explained by the stabilization of the community in general (but not excluding immigration, relaxing and extinction in different rates), including many types of habitats, egg banks and, its availability in the sediment, etc. If this idea is true, other questions can be investigated, including whether the area size is more important that all these appointments on the number of species. Additionally, what are the implications of human interventions in the artificial lakes? In Brazil, there is no information relating to these questions. One reason is the scarcity of natural lakes in this country, as found in other continents, including North America, Africa, Europe, and Asia. Any comparison of natural and artificial lakes in Brazil is restricted to the small-sized environments.

The present study analyzed relations between the species richness of microcrustaceans and areas in natural and artificial (reservoirs) lakes in Brazil. The aims were: (1) To check if areas of Brazilian aquatic environments and microcrustaceans species' richness are positively correlated, according to the biogeographical theories; (2) Compare the relations species-area in natural and artificial aquatic environments, supposing major richness in the natural systems; and (3) To estimate the critical value for aquatic environment areas, from which occurs a stabilization of microcrustaceans' species richness. Our data also contributes to the knowledge of the areas sizing for environmental conservation.

\section{Material and Methods}

The study was based on values of species richness and areas of lakes in Brazil (Figure 1) found in literature, using these key-words in digital basis: Cladocera; cladocerans; Copepoda; copepods; limnology; zooplankton; reservoirs in Brazil; natural lakes Brazil; marginal lakes; floodplain lakes; species richness. There were used the follow basis: Google Schoolar; Scopus; Scielo and ISI Web of Knowledge. The selected papers 
are listed in the Table 1, from 1984 to 2016 . Data from 33 studies involving 83 natural and artificial lakes (dams, reservoirs, ponds) were tabulated for a conjunct analysis of these results. The variables extracted were: area of lakes, type of environment (natural and artificial) and the species richness of Cladocera and Copepoda. Litoranean sites were not added. We found 34 natural lakes and 55 reservoirs, totalizing 89 environments. Same places studied by different authors were added as different studies.

The correlation between richness of cladocerans and copepods was performed using the Spearman's correlation coefficient $\rho$ and tested to the $5 \%$

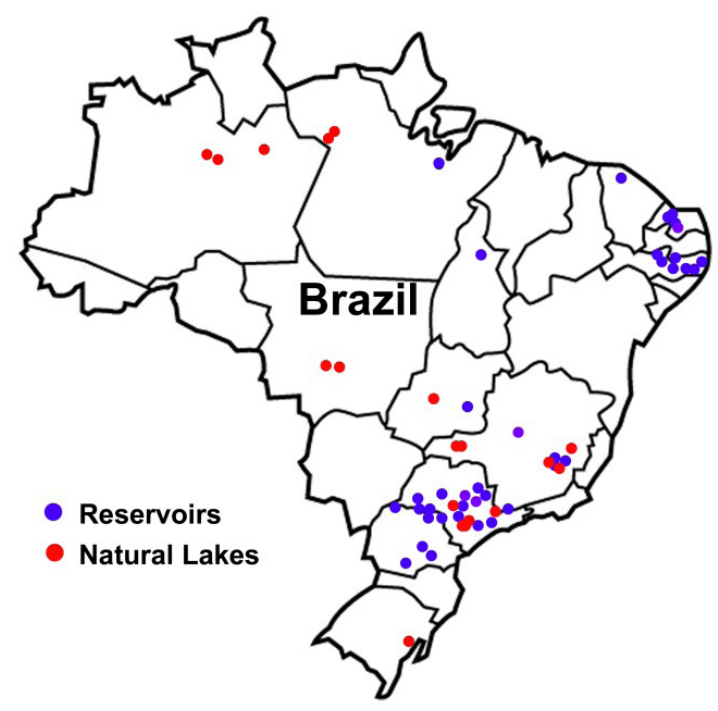

Figure 1. Distribution of the natural (red circles, $\mathrm{N}=32$ ) and artificial (blue circles, $\mathrm{N}=51$ ) lakes used in this study. significance level. Descriptive statistical techniques were used to study the trend of the species richness according to the area and environment type (natural and artificial lakes). Due the similar tendency of microcrustaceans' species, we decide to use a joint analysis (total richness).

While reservoirs areas ranged from 0.01 up to $2430 \mathrm{~km}^{2}$, the natural lakes showed areas smaller than $6 \mathrm{~km}^{2}$ (with the exceptions of Saco de Tapes $\left(189 \mathrm{~km}^{2}\right)$, Tarumã Mirim $\left(10 \mathrm{~km}^{2}\right)$ and Batata lakes $\left.\left(25 \mathrm{~km}^{2}\right)\right)$. The correlation between total richness and area for each environment was analyzed using a Spearman's $\rho$ and tested using t-distribution; the comparison of richness distribution in natural lakes and reservoirs was made using the non-parametric test of Wilcoxon and the homogeneity of variance was studied with Brown-Forsythe test, being all made with $5 \%$ of significance level.

For reservoir data, the relation between total richness and area was described by a piecewise linear model with smooth transition (Equation 1), given by Griffiths \& Miller (1973) and Watts \& Bacon (1974). Similar piecewise formulations were applied by Toms \& Lesperance (2003) in an attempt to estimate ecological thresholds. The model is described as:

$$
y=\beta_{0}+\beta_{1}\left[x-\sqrt[2]{(x-\tau)^{2}+\gamma}\right]
$$

where: $\mathrm{y}$ is the total richness in log scale; $\mathrm{x}$ is the area in log scale $\left(\mathrm{km}^{2}\right) ; \beta_{0}$ and $\beta_{1}$ are parameters associated with the linear phases (pieces) to be joined in the piecewise model; $\gamma$ is a smoothing constant

Table 1. List of studies used in our analysis.

\begin{tabular}{lllc}
\hline \multicolumn{1}{c}{ Name } & Lake type & \multicolumn{1}{c}{ Name } & Lake type \\
\hline Almeida et al. (2009) & Artificial & Mitsuka \& Henry (2002) & Artificial \\
Arcifa (1984) & Artificial & Neves et al. (2003) & Natural \\
Arcifa (1999) & Artificial & Nogueira (2001) & Artificial \\
Bessa et al. (2011) & Artificial & Nogueira et al. (2008) & Both \\
Bohrer et al. (1988) & Artificial & Nogueira \& Panarelli (1997) & Artificial \\
Bozelli (1992) & Natural & Perbiche-Neves et al. (2007) & Artificial \\
Branco et al. (2000) & Artificial & Perbiche-Neves et al. (2013) & Artificial \\
Branco et al. (2002) & Artificial & Perbiche-Neves \& Nogueira (2010) & Artificial \\
Brito et al. (2011) & Artificial & Pinese et al. (2015) & Natural \\
Campanelli Mortari \& Henry (2016) & Natural & Reid et al. (1988) & Both \\
Corgosinho \& Pinto-Coelho (2006) & Artificial & Sampaio et al. (2002) & Artificial \\
Di Genaro et al. (2015) & Artificial & Santos-Wisniewski et al. (2002) & Both \\
Espíndola et al. (2000) & Artificial & Sousa et al. (2008) & Artificial \\
Eskinazi-Sant'Anna et al. (2013) & Artificial & Takahashi et al. (2009) & Artificial \\
Ghidini et al. (2009) & Artificial & Velho et al. (2001) & Artificial \\
Lopes et al. (1997) & Artificial & Vieira et al. (2005) & Natural \\
Maia Barbosa et al. (2008) & Natural & &
\end{tabular}


arbitrarily defined $(\gamma=0.1)$; and the parameter $\tau$ is the critical value for log of area from which the richness seems to stabilize. The log transformation was necessary due to the different orders of magnitude in area measurements.

The fitted model is graphically described as two intercepting straight lines, $y=\beta_{0}+\beta_{1 x}$ and $y=\beta_{0}+\beta_{1} \tau$ (horizontal line), which are joined by a smooth hyperbolic function with curvature controlled by the parameter $\gamma$. The inclusion of the hyperbolic transition is made only to overcome statistical problems in estimation and inference for nonlinear regression, which appear when models have discontinuous derivatives (see Seber \& Wild, 1989). Thus, it allows obtaining more reliable estimates for parameters of the model.

The model was fitted by nonlinear least square technique and non-parametric bootstrapping (2,000 samples) was used for make inferences about the parameters (Bates \& Watts, 1988). All the statistical analyses were carried out with $\mathrm{R}$ software (R Core Team, 2018).

\section{Results}

The species richness of Cladocera and Copepoda were positively associated with area by the Spearman's rank correlation coefficient $(\rho=0.6782 ; \mathrm{p}<0.001$; Figure 2). Using a preliminary descriptive analysis, we verified that cladocerans and copepods richness is similar in the way they are correlated with area of the environments. Thus, we opted in use the total richness of these two groups of organisms as response variable.

In natural lakes there was no correlation between richness and area $(\rho=0.0805 ; p=0.6356)$. However, it is important to note that almost all natural lakes in Brazil are small in size $\left(<6 \mathrm{~km}^{2}\right)$. As mentioned early, only three exceptions are found in our database.

Considering the small sized artificial lakes, similar result was obtained - in dams and reservoirs with area up to $6 \mathrm{~km}^{2}$, there was no significant correlation between richness and area $(\rho=-0.1328$; $\mathrm{p}=0.5556$ ). However, we observed a significant and positive correlation when the data for intermediate and large reservoirs (from 6 to $2430 \mathrm{~km}^{2}$ ) were included in the analyses $(\rho=0.6794 ; \mathrm{p}<0.001)$. The richness increases until a critical point, from which it seems to stabilize (Figure 3).

In small environments $\left(<6 \mathrm{~km}^{2}\right)$ there was different distribution for richness of species in lakes and reservoirs $(\mathrm{W}=524 ; \mathrm{p}<0.001)$, being the largest values found in natural lakes (Figure 4). We also verify at this scale that the richness variance is smaller in reservoirs when compared with natural lakes, since the variances differ by the Brown-Forsythe test ( $\mathrm{W}=11.04 ; \mathrm{p}<0.001)$.

The estimated values obtained to describe total richness of microcrustaceans (copepods + cladocerans)

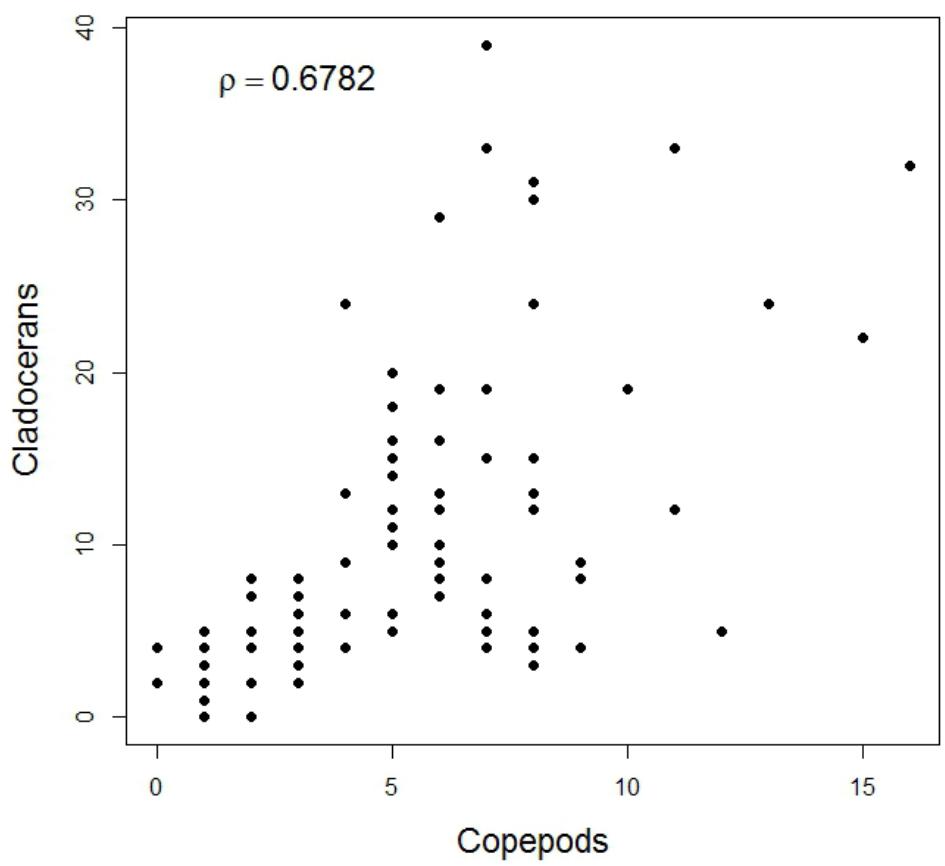

Figure 2. Conjunct distribution of species richness of copepods and cladocerans ( $\bullet$, black circles) and Spearman coefficient pointing a positive association $(\mathrm{p}<0.001)$ for these variables. 

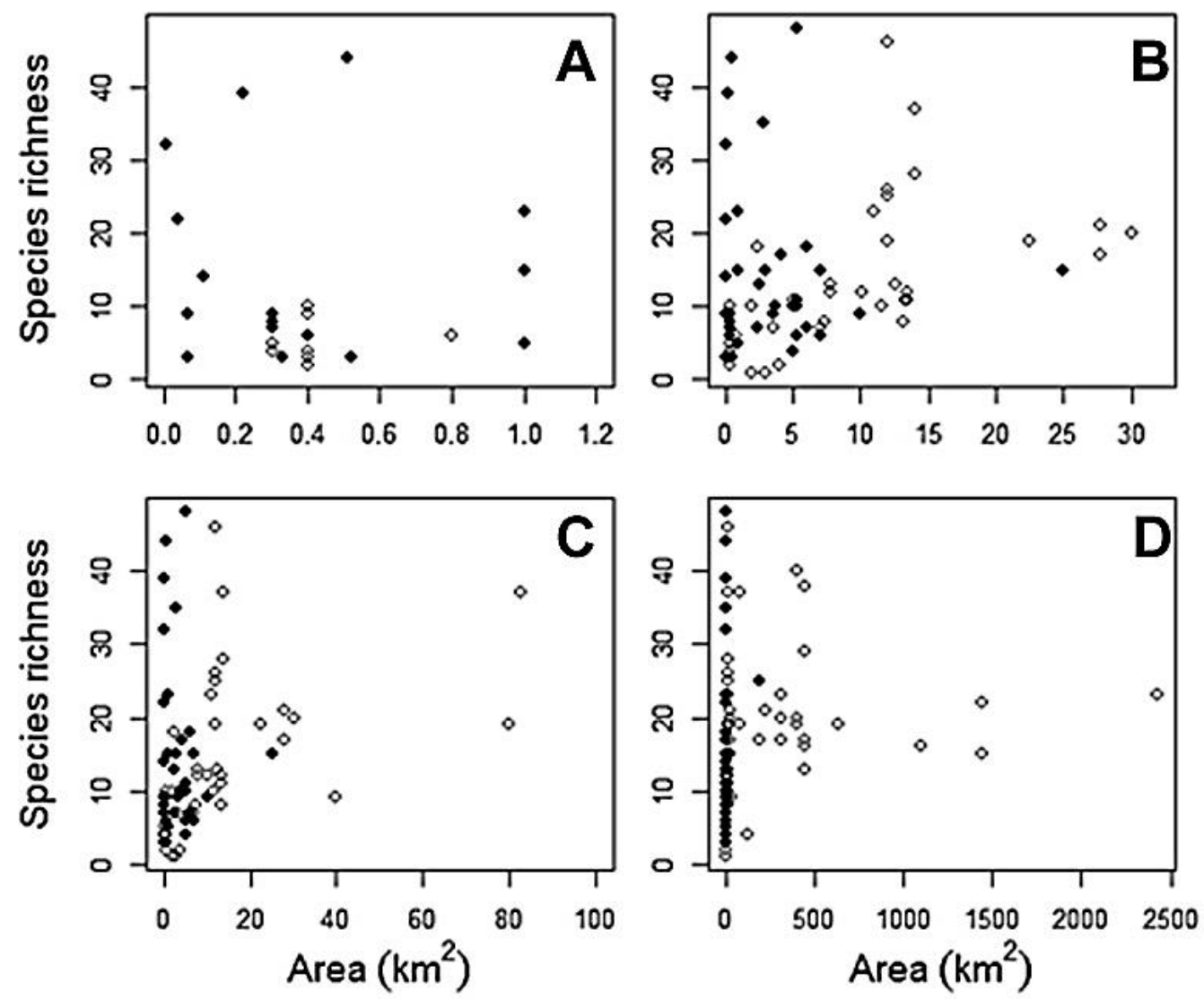

Figure 3. Total richness of microcrustaceans (copepods plus cladocerans) in function to the area of natural lakes (๑, black circles) and reservoirs (O, clear circles), considering lakes between: (A) 0 to $1.2 \mathrm{~km}^{2}$; (B) 0 to $30 \mathrm{~km}^{2}$; (C) 0 to $100 \mathrm{~km}^{2}$; and (D) 0 to $2430 \mathrm{~km}^{2}$.

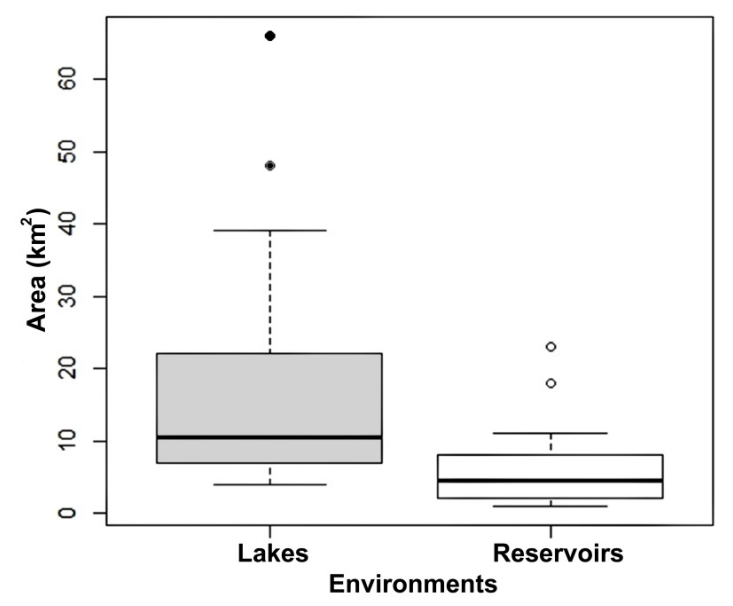

Figure 4. Boxplot of total species richness of microcrustaceans (copepods + cladocerans) in natural lakes (L) and reservoirs (R) until $6 \mathrm{~km}^{2}$ of area. Clear circles are outliers.

in function of the reservoir area, by fitting the piecewise linear model (Equation 1) are presented in Table 2, and the fitted curve is shown in Figure 5.
Table 2. Estimates and percentile confidence intervals for the parameters of the fitted piecewise linear model with hyperbolic smooth transition.

\begin{tabular}{cccc}
\hline Coefficient & Estimative & \multicolumn{2}{c}{ Percentile Cl } \\
\hline & & $2.5 \%$ & $97.5 \%$ \\
$\beta_{0}$ & 2.33 & 2.14 & 2.52 \\
$\beta_{1}$ & 0.18 & 0.11 & 0.27 \\
$\tau$ & 3.66 & 1.93 & 5.49
\end{tabular}

$\mathrm{CI}=$ confidence interval.

As expected, there was a critical point for area from which richness stabilizes. This point was estimated as being 3.66 (in log scale), corresponding to $38.86 \mathrm{~km}^{2}$. The $95 \%$ percentile IC for $\tau$ was $[1.93,5.49]$, indicating that the critical point belongs to the range from 6.89 up to $242.26 \mathrm{~km}^{2}$ with $95 \%$ confidence.

\section{Discussion}

Comparing the natural and artificial lakes, natural lakes are richer and present greater variance in species richness. Even in small environments, 


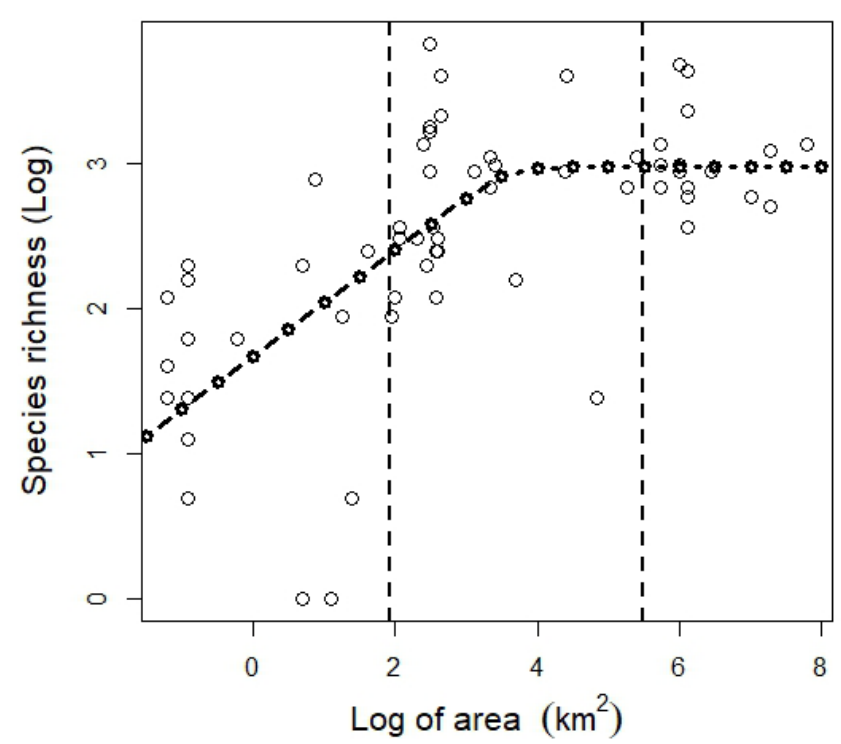

Figure 5. Linear piecewise model with hyperbolic smooth transition fitted to describe total richness of microcrustaceans (copepods + cladocerans) in function of the reservoir area.

natural lakes could present richness superior to that of the largest artificial lakes (Padovesi-Fonseca $\&$ Rezende, 2017). The reason may be the more diversified niche composition in these environments, age, and/or a great variety of biomes. Artificial lakes can be constituted of uniform environments, which give rise to a small richness of microcrustaceans, as reflected in our results.

In small environments, the richness was different between natural and artificial lakes, with higher values for natural lakes. This result contrasts with Merrix-Jones et al. (2013), in which differences have not been found in zooplankton richness between 79 natural and artificial lakes in the world. However, the composition of species was different when considering the variables depth, productivity, longitude, and electrical conductivity. The greater richness in natural lakes in the present study can be attributed to the greater availability of ecological niches in these environments compared to the artificial lakes, which have less heterogeneity (Merrix-Jones et al., 2013). The history of the environment can also interfere as most natural lakes are older than reservoirs, which were generally built after 1950. In small and shallow natural environments, there are usually more aquatic macrophytes, which provide more niches and refuges for zooplankton (Padovesi-Fonseca \& Rezende, 2017).

Natural lakes are associated with less recent events of formation, flood, and eutrophication. When they are of small extension, they have a uniform sedimentary condition and limnetic zones, making possible the proliferation of only a few species of microcrustaceans, as it has composition of poorer niches. In natural environments, the microcrustacean species also had more time to adapt and increase the egg banks in the sediment so that they could be resilient and avail, harmonically, all available resources in the physical environment. This is commented on in the revision about egg banks in the sediment of Gyllström \& Hansson (2004). Meanwhile, in the case of artificial reservoirs, recent disturbances may have affected the ecosystem in such a way that populations of microcrustaceans have efficiently occupied all of the niches that the environment offers, leading to the lowest richness.

The similar behavior to Copepoda and Cladocera richness according to the area can be justified by the habitats and resources that these organisms use. Variations in the vertical column of water and in benthic zones, such as phytoplankton density, luminosity, and flow, should similarly affect the richness of these groups, owing to their ecological similarities.

The differences in the relationship between species' richness and size of area occurs in natural and artificial lakes. Although the natural environments do not exhibit a significant relationship between species area, it resembles the scarcity of large natural lakes in Brazil, and data on medium and large artificial lakes indicated effects of the area on the microcrustaceans' richness.

In statistical problems of regression and correlation, it is known as the influence of the range 
of observations. It is common for conclusions to vary according to the data range (Seber $\&$ Wild, 1989). Our database for artificial environments presents an example of this effect: while a significant correlation between richness and area in small artificial lakes was not found, in the medium and large environments, the total richness of microcrustaceans tends to increase according to the area until it stabilizes to a maximum value. This increase can occur because reservoirs' compartmentalization, new environments and niches, varying according to the morphometric condition and water residence time (Nogueira et al., 2008; Perbiche-Neves \& Nogueira, 2013).

The stabilization point estimate is important because it can be used for the sizing of aquatic conservation areas, such as in the implementation of aquatic preservation areas of small environments. In contrast, large systems will not increase the richness.

The critical point (stabilization) could be estimated at $39 \mathrm{Km}^{2}$, but this estimate was imprecise since its confidence interval is quite wide (7 and $243 \mathrm{Km}^{2}$ ). Generally, artificial lakes with less than $39 \mathrm{Km}^{2}$ have microcrustacean richness up to ideal (equilibrium). The missing of diversity in the microfauna, in turn, places these small environments on the risks of ecological degradation, seen in the importance of microcrustaceans for the support of the trophic chain and quick response for environmental disturbances (Perbiche-Neves et al., 2016).

It was observed that the area does not have any effect on the richness of these species of microcrustaceans in the lakes of small extension (less than six square kilometers), which have great richness variation. Natural small area lakes presented either low values of richness, or values higher than the largest reservoirs, showing the area as a bad predictor of richness in this type of environment. It is possible that the high variation masked the effect of the area on the richness of the species, contradicting a fundamental aspect of the biogeographic theory. The variability of richness among lakes of the same size was likely major compared to the richness area relation, therefore rejecting our hypothesis.

\section{References}

ABELL, R., THIEME, M.L., REVENGA, C., BRYER, M., KOTTELAT, M., BOGUTSKAYA, N., COAD, B., MANDRAK, N., BALDERAS, S.C., BUSSING, W., STIASSNY, M.L.J., SKELTON,
P., ALLEN, G.R., UNMACK, P., NASEKA, A., NG, R., SINDORF, N., ROBERTSON, J., ARMIJO, E., HIGGINS, J.V., HEIBEL, T.J., WIKRAMANAYAKE, E., OLSON, D., LÓPEZ, H.L., REIS, R.E., LUNDBERG, J.G., SABAJ PÉREZ, M.H. and PETRY, P. Freshwater ecoregions of the world: a new map of biogeographic units for freshwater biodiversity conservation. Bioscience, 2008, 58(5), 403-414. http://dx.doi.org/10.1641/ B580507.

ALBERT, J.S. and REIS, R.E. Historical biogeography of neotropical freshwater fishes. Berkeley: University of California Press, 2011. http://dx.doi.org/10.1525/ california/9780520268685.001.0001.

ALMEIDA, V.L., DANTAS, E.W., MELO-JÚNIOR, M., BITTENCOURT-OLIVEIRA, M.C. and MOURA, A.N. Zooplanktonic community of six reservoirs in northeast Brazil. Brazilian Journal of Biology = Revista Brasileira de Biologia, 2009, 69(1), 57-65. http://dx.doi.org/10.1590/S151969842009000100007. PMid:19347146.

ARCIFA, M.S. Zooplankton composition of ten reservoirs in southern Brazil. Hydrobiologia, 1984, 113(1), 137-145. http://dx.doi.org/10.1007/ BF00026600.

ARCIFA, M.S. Ecologia de reservatórios: estrutura, função e aspectos sociais. Botucatu: Fapesp, 1999, pp. 55-76.

BARROS, R.S.M. Medidas de diversidade biológica. Juiz de Fora: Programa de Pós-graduação em Ecologia Aplicada ao Manejo e Conservaçáo de Recursos Naturais, Universidade Federal de Juiz de Fora, 2007.

BATES, D.M. and WATTS, D.G. Nonlinear regression analysis and its applications. Chichester: Wiley, 1988. http://dx.doi.org/10.1002/9780470316757.

BESSA, G.F., VIEIRA, L.C.G., BINI, L.M., REIS, D.F. and MORAIS, P.B. Concordance patterns in zooplankton assemblages in the UHE - Luís Eduardo Magalhães reservoir in the Mid-Tocantins river, Tocantins State, Brazil. Acta Scientiarum: Biological Sciences, 2011, 33(2), 179-184. http://dx.doi. org/10.4025/actascibiolsci.v33i2.7336.

BOHRER, M.B.C., ROCHA, M.M. and GODOLPHIM, B.F. Acta limnologica brasileira: perspectivas na limnologia brasileira. São Carlos: Colab, 1988, pp. 549-570. vol. 2.

BOZELLI, R.L. Composition of the zooplankton community of Batata and Mussura Lakes and of the Trombetas River, State of Para, Brazil. Amazoniana, 1992, 12(2), 239-261.

BRANCO, C.W.C., ESTEVES, F.A. and KOZLOWSKY-SUZUK, B. The zooplankton and other limnological features of a humic coastal lagoon (Lagoa Comprida, Macé, R.J.) in Brazil. Hydrobiologia, 2000, 437(1-3), 71-81. http://dx.doi. org/10.1023/A:1026571301811. 
BRANCO, C.W.C., ROCHA, M.I.A., PINTO, G.F.S., GÔMARA, G.A. and FILIPPO, R. Limnological features of Funil Reservoir (R.J., Brazil) and indicator properties of rotifers and cladocerans of the zooplankton community. Lakes and Reservoirs: Research and Management, 2002, 7(2), 87-92. http:// dx.doi.org/10.1046/j.1440-169X.2002.00177.x.

BRITO, S.L., MAIA-BARBOSA, P.M. and PINTOCOELHO, R.M. Zooplankton as an indicator of trophic conditions in two large reservoirs in Brazil. Lakes and Reservoirs: Research and Management, 2011, 16(4), 253-264. http://dx.doi.org/10.1111/j.14401770.2011.00484.x.

CAMPANELLI MORTARI, R. and HENRY, R. Horizontal distribution of Cladocera in a subtropical lake marginal to a river. Journal of Limnology, 2016, 75(1), 109-120.

CONNOR, E.F. and MCCOY, E.D. Species-area relationships. In: S.A. LEVIN, ed. Encyclopedia of biodiversity. San Diego: Academic Press, 2001, pp. 397-411. vol. 5. http://dx.doi.org/10.1016/B0-12226865-2/00252-2.

CONNOR, E.F. and MCCOY, E.D. The statistics and biology of the species-area relationship. American Naturalist, 1979, 113(6), 791-833. http://dx.doi. org/10.1086/283438.

CORGOSINHO, P.H.C. and PINTO-COELHO, R.M. Zooplankton biomass, abundance and allometric patterns along an eutrophic gradient at Furnas Reservoir (Minas Gerais, Brazil). Acta Limnologica Brasiliensia, 2006, 182, 213-224.

DENGLER, J. Which function describes the species-area relationship best? A review and empirical evaluation. Journal of Biogeography, 2009, 36(4), 728-744. http:// dx.doi.org/10.1111/j.1365-2699.2008.02038.x.

DI GENARO, A.C., SENDACZ, S., MORAES, M.A.B. and MARCANTE, C.T.J. Dynamics of Cladocera Community in a Tropical Hypereutrophic Environment (Garças Reservoir, São Paulo, Brazil). Journal of Water Resource and Protection, 2015, 7(05), 379-388. http://dx.doi.org/10.4236/ jwarp.2015.75030.

DRAKARE, S., LENNON, J.J. and HILLEBRAND, $H$. The imprint of the geographical, evolutionary and ecological context on species-area relationships. Ecology Letters, 2006, 9(2), 215-227. http:// dx.doi.org/10.1111/j.1461-0248.2005.00848.x. PMid:16958886.

ESKINAZI-SANT'ANNA, E.M., MENEZES, R., COSTA, I.S., ARAÚJO, M., PANOSSO, R. and ATTAYDE, J.L. Zooplankton assemblages in eutrophic reservoirs of the Brazilian semi-arid. Brazilian Journal of Biology $=$ Revista Brasileira de Biologia, 2013, 73(1), 37-52. http://dx.doi. org/10.1590/S1519-69842013000100006.
ESPÍNDOLA, E.L.G., MATSUMURA-TUNDISI, T., RIETZLER, A.C. and TUNDISI, J.G. Spatial Heterogeneity of the Tucuruí Reservoir (State of Pará, Amazonia, Brasil) and the Distribution of Zooplanktonic Species. Revista Brasileira de Biologia, 2000, 60(2), 179-194. http://dx.doi.org/10.1590/ S0034-71082000000200001. PMid:10959101.

GHIDINI, A.R., SERAFIM-JÚNIOR, M., PERBICHE-NEVES, G. and BRITO, L. Distribution of planktonic cladocerans (Crustacea: Branchiopoda) of a shallow eutrophic reservoir (Paraná State, Brazil). Pan-American Journal of Aquatic Sciences, 2009, 4(3), 294-305.

GRIFFITHS, D.A. and MILLER, A.J. Hyperbolic regression - a model based on two-phase piecewise linear regression with a smooth transition between regimes. Communications in Statistics, 1973, 2(6), 561-569. http://dx.doi.org/10.1080/03610927308827098.

GYLLSTRÖM, M. and HANSSON, L.A. Dormancy in freshwater zooplankton: induction, termination and the importance of benthic-pelagic coupling. Aquatic Sciences, 2004, 66, 274-295. http://dx.doi. org/10.1007/s00027-004-0712-y.

LOMOLINO, M.V. The species-area relationship: new challenges for an old pattern. Progress in Physical Geography, 2001, 25, 1-21.

LOPES, R.M., LANSAC-TÔHA, F.A., VALE, R. and SERAFIM, M. Comunidade zooplanctônica do reservatório de Segredo. In: A.A. AGOSTINHO and L.C. GOMES, eds. Reservatório de Segredo: bases ecológicas para o manejo. Maringá: EDUEM, 1997, 387 p.

MAIA-BARBOSA, P.M., PEIXOTO, R.S. and GUIMARÃES, A.S. Zooplankton in littoral waters of a tropical lake: a revisited biodiversity. Brazilian Journal of Biology = Revista Brasileira de Biologia, 2008, 68(4), 1069-1078, Supplement. http:// dx.doi.org/10.1590/S1519-69842008000500014. PMid:19197477.

MERRIX-JONES, F.L., THACKERAY, S.J. and ORMEROD, S.J. A global analysis of zooplankton in natural and artificial fresh waters. Journal of Limnology, 2013, 72(1), 140-153. http://dx.doi. org/10.4081/jlimnol.2013.e12.

MITSUKA, P.M. and HENRY, R. The fate of copepod populations in the Paranapanema River (São Paulo, Brazil), downstream from the Jurumirim dam. Brazilian Archives of Biology and Technology, 2002, 45(4), 479-490. http://dx.doi.org/10.1590/S151689132002000600012 .

NEVES, I.F., ROCHA, O., ROCHE, K.F. and PINTO, A.A. Zooplankton community structure of two marginal lakes of the River Cuiabá (Mato Grosso, Brazil) with analysis of Rotifera and Cladocera diversity. Brazilian Journal of Biology $=$ Revista Brasileira de Biologia, 2003, 63(2), 329-343. http:// 
dx.doi.org/10.1590/S1519-69842003000200018. PMid:14509855.

NOGUEIRA, M.G. Zooplankton composition, dominance and abundance as indicators of environmental compartmentalization in Jurumirim Reservoir (Paranapanema River), São Paulo, Brazil. Hydrobiologia, 2001, 455(1-3), 1-18. http://dx.doi. org/10.1023/A:1011946708757.

NOGUEIRA, M.G. and PANARELLI, E. estudo da migração vertical das populaçóes zooplanctônicas na Represa de Jurumirim (Rio Paranapanema - São Paulo, Brazil). Acta Limnologica Brasiliensia, 1997, 9, 55-81.

NOGUEIRA, M.G., REIS-OLIVEIRA, P.C. and BRITTO, Y.T. Zooplankton assemblages (Copepoda and Cladocera) in a cascade of reservoirs of a large tropical river (SE Brazil). Limnetica, 2008, 27(1), 151-170.

PADOVESI-FONSECA, C. and REZENDE, R.S. Fatores que determinam a diversidade de zooplâncton em lagoas rasas de Savana Neo-Tropical. Acta Limnologica Brasiliensia, 2017, 29, e15.

PERBICHE-NEVES, G. and NOGUEIRA, M.G. Multi-dimensional effects on Cladoceran (Crustacea, Anomopoda) assemblages in two cascade reservoirs in Southeast Brazil. Lakes and Reservoirs: Research and Management, 2010, 15(2), 139-152. http://dx.doi. org/10.1111/j.1440-1770.2010.00429.x.

PERBICHE-NEVES, G. and NOGUEIRA, M.G. Reservoir design and operation: effects on aquatic biota a case study of planktonic copepods. Hydrobiologia, 2013, 707(1), 187-198. http://dx.doi. org/10.1007/s10750-012-1425-1.

PERBICHE-NEVES, G., FILETO, C., LACO PORTINHO, J., TROGUER, A. and SERAFIM JUNIOR, M. Relations among planktonic rotifers, cyclopoid copepods, and water quality in two Brazilian reservoirs. Latin American Journal of Aquatic Research, 2013, 41(1), 138-149. http://dx.doi. org/10.3856/vol41-issue1-fulltext-11.

PERBICHE-NEVES, G., PREVIATTELLI, D., PIE, M.R., DURAN, A., SUÁREZ-MORALES, E., BOXSHALL, G.A., NOGUEIRA, M.G. and ROCHA, C.E. Historical biogeography of the neotropical Diaptomidae (Crustacea: Copepoda). Frontiers in Zoology, 2014, 11(1), 36. http://dx.doi. org/10.1186/1742-9994-11-36. PMid:25057279.

PERBICHE-NEVES, G., SAITO, V.S., PREVIATTELLI, D., ROCHA, C.E.F. and NOGUEIRA, M.G. Cyclopoid copepods as bioindicators of eutrophication in reservoirs: do patterns hold for large spatial extents? Ecological Indicators, 2016, 70, 340-347. http://dx.doi. org/10.1016/j.ecolind.2016.06.028.

PERBICHE-NEVES, G., SERAFIM-JÚNIOR, M., GHIDINI, A.R. and BRITO, L.R. Spatial and temporal distribution of Copepoda (Cyclopoida and Calanoida) of an eutrophic reservoir in the basin of upper Iguaçu River, Paraná, Brazil. Acta Limnologica Brasiliensia, 2007, 19(4), 393-406.

PINESE, O.P., PINESE, J.F. and DEL CLARO, K. Structure and biodiversity of zooplankton communities in freshwater habitats of a Vereda Wetland Region, Minas Gerais, Brazil. Acta Limnologica Brasiliensia, 2015, 27(3), 275-288. http://dx.doi.org/10.1590/S2179-975X0415.

R CORE TEAM. A language and environment for statistical computing. Vienna: R Foundation for Statistical Computing, 2018.

REID, J.W., PINTO-COELHO, R.M. and GIANI, A. Uma apreciação da fauna de copépodos (Crustacea) da região de Belo Horizonte, com comentários sobre espécies de Minas Gerais. Acta Limnologica Brasiliensia, 1988, 2, 527-547.

ROSENZWEIG, M.L. Species diversity in space and time. Cambridge: Cambridge University Press, 1995. http://dx.doi.org/10.1017/CBO9780511623387.

SAMPAIO, E.V., ROCHA, O., MATSUMURATUNDISI, T. and TUNDISI, J.G. Composition and abundance of zooplankton in the limnetic zone of seven reservoirs of the Paranapanema River, Brazil. Brazilian Journal of Biology = Revista Brasileira de Biologia, 2002, 62(3), 525-545. http:// dx.doi.org/10.1590/S1519-69842002000300018. PMid:12530191.

SANTOS-WISNIEWSKI, M.J., ROCHA, O., GUNTZEL, A.M. and MATSUMURA-TUNDISI, T. Cladocera Chydoridae of high altitude water bodies (Serra da Mantiqueira), in Brazil. Brazilian Journal of Biology $=$ Revista Brasileira de Biologia, 2002, 62(4), 681-687. http://dx.doi.org/10.1590/ S1519-69842002000400016. PMid:12659018.

SEBER, G.A.F. and WILD, C.J. Nonlinear regression. Hoboken: John Wiley \& Sons, 1989, 768 p. http:// dx.doi.org/10.1002/0471725315.

SILVA, W.M. and PERBICHE-NEVES, G. Trends in freshwater microcrustaceans studies in Brazil between 1990 and 2014. Brazilian Journal of Biology = Revista Brasileira de Biologia, 2016, 77(3), 527534. http://dx.doi.org/10.1590/1519-6984.17915. PMid:27925015.

SOUSA, W., ATTAYDE, J.L., ROCHA, E.D.S. and ESKINAZI-SANT'ANNA, E.M. The response of zooplankton assemblages to variations in the water quality of four man-made lakes in semi-arid northeastern Brazil. Journal of Plankton Research, 2008, 3(6), 699-708. http://dx.doi.org/10.1093/ plankt/fbn032.

TAKAHASHI, E.M., LANSAC-TÔHA, F.A., DIAS, J.D., BONECKER, C.C. and VELHO, L.F.M. Spatial variations in the zooplankton community from the Corumbá Reservoir, Goiás State, in distinct 
hydrological periods. Acta Scientiarum: Biological Sciences, 2009, 31(3), 227-234.

TOMS, J.D. and LESPERANCE, M.L. Piecewise regression: a tool for identifying ecological thresholds. Ecology, 2003, 84(8), 2034-2041. http://dx.doi. org/10.1890/02-0472.

VELHO, L.F.M., LANSAC-TÔHA, F.A., BONECKER, C.C., BINI, L.M. and ROSSA, D.C. The longitudinal distribution of copepods in Corumbá Reservoir, state of Goias, Brazil. Hydrobiologia, 2001, 453-454, 385391. http://dx.doi.org/10.1023/A:1013194118104.

VIEIRA, L.C.G., MARQUES, G.S. and BINI, L.M. Estabilidade e persistência de assembléias zooplanctônicas em um pequeno lago tropical.
Acta Scientiarum: Biological Sciences, 2005, 27(4), 323-328.

WATTS, D.G. and BACON, D.W. Using a hyperbola as a transition model to fit two-regime straight-line data. Technometrics, 1974, 16(3), 369-373. http://dx.doi. org/10.1080/00401706.1974.10489205.

WILLIAMSON, M. Relationship of species number to area, distance and other variables. In: A.A. MYERS and P.S. GILLER, eds. Analytical biogeography: an integrated approach to the study of animal and plant distributions. London: Chapman \& Hall, 1988, pp. 91-115.

Received: 09 March 2018 Accepted: 03 October 2018 